University of Michigan Law School

University of Michigan Law School Scholarship Repository

1913

\title{
The Teaching of Practice and Procedure in Law Schools
}

\author{
Edson R. Sunderland \\ University of Michigan Law School
}

Available at: https://repository.law.umich.edu/articles/1063

Follow this and additional works at: https://repository.law.umich.edu/articles

Part of the Civil Procedure Commons, Comparative and Foreign Law Commons, and the Legal Education Commons

\section{Recommended Citation}

Sunderland, Edson R. "The Teaching of Practice and Procedure in Law Schools." Am. L. Sch. Rev. 3 (1913): 357-67. (Originally published under the same title in Proceedings of the Association of American Law Schools 13 (1913): 47-62. Also published in Report of the Annual Meeting (Amer. Bar Assoc. ) 38 (1913): 908-32.)

This Article is brought to you for free and open access by the Faculty Scholarship at University of Michigan Law School Scholarship Repository. It has been accepted for inclusion in Articles by an authorized administrator of University of Michigan Law School Scholarship Repository. For more information, please contact mlaw.repository@umich.edu. 


\section{The Teaching of Practice and Procedure in Law Schools}

By EDSON R. SUNDERLAND

Professor of Law, University of Michigan

(A paper read before the Association of American Law Schools at Montreal, Canada, September 1, 1913.)

$\mathrm{C}^{\mathrm{R}}$

RITICISM of the law, the courts, and the legal profession is one of the popular customs of the day. So constantly and so insistently are we told of the shortcomings of the Bench and Bar that it is hard to hold one's footing against the sweep of the current. One might well suppose from all the clamor that the ancient respectability of the law had suddenly been discovered to be a monstrous pretense, a fraud on the innocence and trustfulness of the people, a cloak for injustice and a mask for oppression.

But the whole phenomenon is simply an instance of the overemphasis which 
always characterizes the human attitude. And this is not to be deprecated, for only in that way can social inertia be overcome and the impulse toward reform be given the necessary momentum.

Progress is an alternating, not a continuous, movement. In all phases of life a period of hopeful activity is normally succeeded by a period of critical retrospect. We push ahead with our work and our plans until something goes wrong, and then we stop, try to diagnose the trouble, revise our program in the light of our experience, and go on again along new lines. This ebb and flow of thought and action is characteristic of life. Hegel, the greatest philosopher of modern times, found in it a basis for a theory of metaphysics in which he exhibited the world as a systematic selfdevelopment through the agency of this inherent tendency to intermittent movement due to the experimental nature of all rational progress. Such a philosophy is full of the sparkle of optimism, for it turns our mistakes into indispensable stepping stones to better things.

We are now in the midst of a critical stage in this process of social self-development. Things have not turned out as well as we anticipated, and we have stopped to analyze the situation and propose remedies. Disappointment and discontent are widespread and the spirit of unrest pervades everything. Nothing has entirely escaped.

It would be strange indeed if the law, which touches society so closely, were not included in the dragnet indictment which public opinion has found against modern social institutions. But the gist of the charge has been the administration of the law, not the law itself. With popular legislative assemblies constantly employed in enacting statutes with the sole apparent purpose of pleasing every pass- ing whim of the people, there could hardly be any plausible excuse for the complaint that the lawmaking power is not responsive to popular wishes. The people seem to have just the laws and all the laws they want. Statutes appear quite fully abreast of current ideas.

But it is different with legal administration. Here the people act through a highly trained but conservative profession, the members of which are not directly responsible to the electorate. The legislature may formulate the standards for admission to the Bar, but the Bar fixes its own standards of professional conduct. Discretion necessarily plays so large a part in judicial administration, and personal capacity and skill are such determining factors in the complex problems of professional work of all kinds, that the legislature can do scarcely more than prescribe formal rules for the guidance of litigation. It can do little to control the manner of their use. But while the profession feels its independence, cherishes its ideals, honors its traditions, and pursues its way in comparative freedom from the fussy regulation of the legislature, it is subject to a power far more potent. The inexorable laws of supply and demand, of competition and the survival of the fittest, guide the destiny of the lawyer as well as the wage-earner or the business man. These are laws of nature which nothing can withstand.

Lawyers are quasi-public servants. They are licensed and employed to accomplish certain purposes. They exist for the benefit of the public. Those who offer what the public will not have must change their ways or go unemployed. The public has become convinced that there is gross inefficiency in the administration of the law. It has weighed current procedure in the balance and found it wanting. There is too much delay, ex- 
pense, and uncertainty about it. It does not produce results commensurate with the effort employed.

Many causes contribute to this. One is that there is too little regard paid to the finer ethical standards in the employment of the processes of the law. Technical rules are capable of a beneficent and a malignant use. The lawyer is much less likely to forget his duty to his client than to the court and the public. In the stress and strain of litigation he is too ready to resort to technicalities for the purpose of confusing the evidence, diverting the issues, and laying a founda-, tion for a vexatious appeal, when success upon the merits seems out of reach. It is the "nuisance value" of the rules of procedure which then appeals to him, and it is their "nuisance value" that has discouraged and disgusted the public. No legislation can reach this problem. It is essentially ethical, and the solution lies with the Bench and Bar.

But concurrent with this perverted view of the function of procedure is an apparently inconsistent condition, namely, widespread lack of precision and effectiveness in the use of procedure. We lose our respect for what we habitually misuse. Its logic is lost in the maze of its petty rules; its true purpose is forgotten in the stress of the case in hand.

But procedure, when rightly considered, is the very life of the law. It is that which renders litigation possible. Procedure is merely the means of co-ordinating effort, of harmonizing differences, of offering every one equality of opportunity in offense and defense before the law. Without it there would be confusion, favoritism, and injustice. If the subject were viewed in this fundamental way, and were studied conscientiously as an incident and aid to the development and determination of the merits of con- troversies, the criticisms now so fiercely directed against it would largely disappear. In its use it is indispensable, in its abuse only does it cause trouble. A professional conscience to curb that abuse, and professional learning and skill to direct its proper use, are the two needs of the time.

Perhaps the law schools have a part to play in the attainment of both these ends. For law and ethics are twin sisters. But the primary problem of the schools is to develop true and comprehensive intellectual conceptions. So far as procedure is concerned, it seems clear that they have failed to appreciate the magnitude of the task and have done little to correct the deficiencies which ine public is so insistently pointing out.

Procedure has always been a difficult and technical part of the law. In its primitive condition, law was not much more than a system of procedural forms. Gradually the law of rights obtained the ascendency over the law of remedies, and procedure lost its claim to an independent valuation and became a means to the investigation and determination of litigated controversies.

Viewing procedure in this modern way, two aspects at once present themselves for consideration. It may be looked at as both a mechanism and a mode of operation. And this distinction is important. Let there be devised ever so good a system, yet its value may be destroyed by clumsy methods of use. On the other hand, with a crude and cumbersome system excellent results may be reached by operative skill. The system itself is a matter over which the legislature has assumed direct jurisdiction, while the mode and manner of its application has necessarily been left largely to the Bench and Bar.

Such a division of responsibility is un- 
fortunate, for there is so close an interrelation between the machinery and its operation that a constant and free co-adjustment should be at all times possible. The excellence of a procedural system is to be tested by the ease with which it lends itself to practical use. As practice discloses weaknesses in its fabric, the practitioners themselves should be free to devise amendments and changes calculated to remedy such defects. The users should be also the designers and adjusters. Such is the case in England, where the judges enact and amend the rules which they themselves administer.

But the legal profession in the United States, though it may not have direct authority and control over the rules of procedure, is nevertheless charged with the duty of doing the best it can with the means at its command. If those means are thought to be not of the best, so much the more skill is called for on the part of the profession. Lawyers may not be immediately responsible for fancied imperfections in the system, but they are certainly chargeable with inefficiency in the use of it.

It must also be remembered that procedure is the one branch over which the legal profession is vested with a peculiar and exclusive jurisdiction. While the trained lawyer must understand legal relations in all their phases if he is to be a proper adviser for his clients, his professional characteristic is his authority, and presumably his ability, to use the procedural machinery of the law. Many lawyers never go into court, and confine themselves to a consultation practice. But their advice is predicated upon an understanding of what they might be permitted or required to do if they were to resort to the courts, and, though they do not themselves employ procedural processes, the value of their suggestions depends upon the accuracy with which they gauge the procedural possibilities in the case before them.

The legal profession in the United States has never taken procedure as seriously as has the profession in England, and it would hardly be amiss to ascribe our much-criticised inefficiency quite largely to this cause. The English professional system, with its division of functions between barristers and solicitors, is based upon the broad doctrine that procedure is of first importance. The barrister is the trial lawyer. He is also a consultation lawyer. A consultation practice is thus combined with the most technically exacting work of trial practice. Instead of freedom from court work being conducive to the development of ability as a giver of legal advice, just the reverse seems to be true. The barristers as a class are a most learned body of lawyers. From their ranks the Eng lish judges are drawn. To them is due the credit for English legal efficiency, because they are experts in procedure. Trials conducted by such men, gifted by native ability and rich in a long and varied experience in the conduct of litigation, could not fail to be models of rapid and accurate work. To them the court room is the shrine of the law. Instead of belittling procedure they exalt it as the method by which alone rights can be safely, quickly, and accurately determined.

I take it to be clear, therefore, that the professional equipment of the lawyer ought to include a reasonable familiarity with the fundamental rules under which remedies are obtained in the courts. And it follows that the law schools, which are established to prepare lawyers for professional work, ought to do what is rea- 
sonably possible to give them the necessary training in the principles of procedure.

There is, as I look at it, a striking and far-reaching difference in the functions of the colleges of liberal arts and the professional schools. Both are established in the public interest. But while the aim of the former is to develop individual character and mental strength, the latter are expected to produce efficient practitioners. It is of little concern to the college educator whether his students study mathematics, or Greek, or history, for he knows that all roads lead to Rome. He wants to develop the mental powers of his students and to bring them into contact with the best thought of the world's great minds. If he does this he does his duty, for he turns out men with the furnishings and training requisite to broad citizenship. Not so with the professional school. Its task is to train men to do well the technical work expected from their profession. It looks to skillful performance in certain lines of activity. The test of its success is the efficiency of its output. The gradually increasing entrance requirements among the better professional schools mean nothing else than a recognition of the truth that such schools are not a part of the general educational system, but are institutions into which the already educated man comes for special training to fit him for a special service. The law school does not justify its existence by contending that a legally trained mind makes a good citizen, though that may be entirely true. It justifies itself by asserting that the country needs well-trained lawyers and by showing that it can produce them. Accordingly, the law schools, in order to fully fill the place for which they have been created and maintained, should give their students a complete preparation for all that the practice of the profession will afterwards demand of them.

But the truth is that the schools have never taken hold of procedure in a thoroughgoing and comprehensive way. They have followed the beaten path and nothing more. The great foundation subjects of contracts, torts, and property have been developed with consummate skill, and are presented in the better schools with a breadth of philosophical insight which leaves little to be desired. Instead of being taught in isolated, fragmentary bits, the whole subject in its logical completeness is unfolded before the student, so that he feels and understands its principles, its boundaries, its purposes, and its relations. Such a method of study develops a feeling or attitude toward a subject which becomes a sort of intuitive guide in the solution of its problems. Such a method produces results which time cannot destroy, and the student's knowledge does not melt away with the first lapse of memory.

Why is not procedure taken up in the same far-sighted way? It is not because of any want of importance, as has already been shown. Apparently the schools have not progressed far enough yet.

No school teaches procedure under that name. Few teach it at all. Most schools teach pleading and evidence, with a course on equity practice and another on criminal procedure. Such a division of subjects is like separate courses on consideration and promises instead of a course on contracts, in which the main thing would be left out, namely, the corelation of the parts, which is the real significance of each. But the case of procedure is worse. For if all the parts of a subject are taught even in fragments, there is at least no positive gap left unfilled. But the procedure subjects 
taught in most law schools do not cover procedure. Not only is the coördination of parts missing, but one of the chief parts is itself a fugitive and an outcast.

If procedure is looked at in a broad way, it is a single subject. Its aim, as already pointed out, is to supply a mechanism for litigation. One purpose runs through it all, and all its parts fit together like cogs in a gear. Pleadings are drawn to present issues for trial; trials are had to determine issues raised by the pleadings. Rules of evidence determine admissibility, but the foundation of the proof is the pleadings. The jury must base its verdict and the court its decision upon what the pleadings allege and the evidence tends to prove, and instructions are to be drawn within the scope of both. The same principles which limit evidence place restrictions upon the conduct and argument of counsel. Upon the relation between the pleadings and the evidence depends the right to take the case from the jury. Appeals and writs of error call in question principles of pleading, of evidence, and of trial practice. In truth, the writ, the pleadings, the trial, the verdict, the judgment, and the appeal are a connected series of elements each one depending upon the others, each comprehensible only through the others, each supplementary to the rest. To isolate pleading and evidence, take them out of their setting, treat them as absolute instead of relative, and ignore the rest of the subject, is misleading. Only when one understands the problems, the purpose, and the logic of procedure as a whole can he understand the real significance of the rules relating to its separate branches.

The truth probably is that the most important as well as the most illuminating portion of procedure is trial practice, which the law schools largely ignore.
The trial is the end and essence of procedure. It is the center about which all other procedure subjects revolve. To really understand the trial is to understand procedure. The pleadings lead up to it, the evidence is part and parcel of it, the appeal grows out of it. The trial is the heart of procedure.

A glance at the function of the jury in the modern trial at law will make the point clear. It is the jury which is the characteristic feature of the trial, coloring all its phases and determining most of its rules. This is the institution which has made common-law procedure what it is. There is scarcely anything about the trial, from the pleadings to the writ of error, which does not reflect the influence of this unique feature of English and American legal development. The pleadings are drawn to produce issues triable to a jury; the trial opens with the selection of the jury; the conduct of counsel, from opening statement to final argument, is hedged about with restrictions due to the presence of the jury; the rules of evidence are all devised to meet the peculiar requirements of the jury; the whole theory of nonsuits and directed verdicts arises out of the division of functions between court and jury; the difficult and important subject of instructions to the jury obviously rests upon the same conception; special interrogatories and special verdicts are merely devices for penetrating into the conscience of the jury; new trials, with their vastly complicated rules, were devised and are granted as a safeguard against perverse verdicts of juries; the verdict is the final decision of the jury and it fixes the character of the judgment; and the writ of error is sued out or the appeal is taken in most cases because the appellant believes he can convince the court that some error was com- 
mitted in the presence of the jury which prejudicially influenced its verdict, and he prays for a reversal and another trial before another jury.

Equity procedure is much simpler. But with it I am not now concerned. It is usually taught in connection with equity pleading and gives little trouble.

Now, if the whole doctrine of civil procedure at law has been developed and is administered with a view to preserving the division of functions between the court and jury, segregating issues and questions of fact from issues and questions of law, that conception would appear to offer a logical center about which to group the various special subjects embraced within the general field. And that means that Trial Practice, which concerns itself with the rules relating to the conduct of the trial itself, is the essential and significant title in procedure.

A well-balanced system of instruction in procedure ought therefore to group all procedure branches about the trial as the procedural center. They should be coördinated with a view to their purpose as ancillary and incidental to the trial, for their meaning, scope, and importance are strictly dependent thereon.

The teaching of trial practice has scarcely been attempted in most of the law schools of this country. And the reason probably lies in the failure to clearly distinguish between trial practice as a body of well-defined and accurately developed principles of procedure and trial practice as a vague and shadowy discourse on success in advocacy. The law schools cannot undertake to teach men how to read character; how to cultivate an impressive manner; how to skillfully interrogate a witness; how and when to appeal to the emotions of the jury; how to delicately flatter or severely arraign. They cannot teach resource- fulness and tact. The art of expression and the skill of strategy are outside the proper scope of the schools of law. Al! of these things are as necessary in selling goods or teaching school as in practicing law. The art of advocacy is the art of life, and only life can teach what life is.

But if trial practice is viewed as the keystone of a systematic scheme of procedure, concerning itself with the principles by which the problems pertaining to the conduct of the trial are analyzed and solved, it becomes a very different thing. Such a subject is accurate, logical, and professionally technical. It concerns the very essence of procedure, and it is as solidly intellectual as any other branch of the law.

A glance at the subject-matter embraced by the notion of the trial will at once disclose its adaptability to law school instruction. It includes the scope, plan, and purpose of the statutory systems for obtaining venires, and the theory of their interpretation; the doctrines relative to the examination of jurors on their voir dire, and bias and challenges; the functions of the opening statement and the right to open and close; the principles underlying the different methods of withdrawing the case from the jury, such as nonsuit, directed verdict, and demurrer to the evidence; the theory and practice of preparing instructions for the jury; the purpose and propriety of special interrogatories and special verdicts; the doctrine of new trials and the conditions and limitations under which they may be granted; the rules regulating the conduct of counsel while in the presence of the jury.

All these subjects, with perhaps two or three others, are of primary importance to the lawyer who appears in court. They have been worked out accurately 
and comprehensively by the courts in a vast array of decisions. They are based on the closest logic and the broadest policy. They have called forth the best thought of able judges. They lie at the very heart of our judicial system, for of what value are rights if remedies fail.

The trial serves a single and perfectly definite purpose. Trial practice, which concerns its conduct, is not a mere collection of unrelated rules, but a closely articulated subject, in which every part bears a demonstrable relation to every other and to the whole. A study of it gives unity to procedure, and puts vitality into many a dry rule. Pleading and evidence can never stand forth in their true significance until they have been given their proper place as incidents of the trial.

Now, so far as concerns the question, how to teach practice, it is quite obvious that the principles of the subject can be taught in exactly the same way as any other branch of the law, except that I believe the case system is more imperatively necessary than elsewhere. In all procedure subjects the principles depend so intimately on the facts of the cases in hand that they mean little when divorced from the facts. And this is especially true of trial practice.

One common fallacy has perhaps done much to deter the schools from seriously taking up the subject, and that is the prevalent idea that trial practice is essentially local in its close dependence ort statutes and court rules. But the reverse is more nearly the truth. The basic principles underlying the subject are absolutely general in their scope and application. Variations occur in minor points, but I believe there is no subject of the law, either in procedure or the substantive branches, where there is less diversity in fundamentals and in the princi- ples of interpretation than in trial practice.

If it be conceded that trial practice should be taught, another step logically suggests itself. The student of chemistry is taught the principles of qualitative analysis, but he is also taught how to put those principles to use in analyzing unknown combinations of chemical substances. The engineering student is taught in shop courses how to apply the principles learned in the books. Medical and dental students have clinical cases to work upon. Why should not the law student have cases in procedure? The practice court constitutes the affirmative answer of many law schools to this question. But I am inclined to think that the development of practice courts has been hampered by an incorrect conception of their true function.

A practice court is certainly not a mere imitation of a real court. It cannot survive amid the press of work in the brief period allowed for modern legal education unless it does something more than allow men to play they are lawyers. Going through the motions of a trial, even under the supervision and criticism of a competent teacher, is in itself a comparatively unproductive process.

On the contrary, the practice court should be a means and method for actually coördinating the various branches of procedure. It should furnish an opportunity for the students to marshal the principles of procedure as studied theoretically, and employ them in analyzins and solving specific problems of litigation. It should teach a method of attack. To do this it must provide much more than a court room, a judge, and a jury.

To produce a law school trial which shall serve a useful educational purpose, there must be two things: First, a set of facts must be developed analogous to the 
facts in a litigated controversy ; and, second, there must be a thorough and technical preparation of those facts in all their legal possibilities, by students representing both sides of the controversy.

The first may be done by arranging actual transactions among students selected from the school, and carrying them out in such a way that issues of fact respecting them shall develop. Suppose a dozen men are called upon to serve as actors and witnesses in a case. The character under which each appears, such as that of a contractor or a bank cashier, is assumed. In that capacity each proceeds to take the part assigned, carrying on conversations, executing paperrs, writing letters, telephoning, or doing whatever is requisite to fill out the schedule of events which the instructor has devised to raise suitable issues of fact. It is easy for the actors to be coached as to what to do and say. After the words are spoken or the acts are performed, they become as properly the subject of future investigation as do any of those events which form the basis of actual lawsuits. The actors can truthfully testify as to what they did; the witnesses may relate what they saw and heard. The case exists only in the doings of those actors, and students assigned to the case as attorneys have access to the same sort of evidence that the practicing lawyer deals with. The case is in every sense an actual case, though artificially produced. It is not assumed. Practically everything that will be shown in evidence will have actually happened.

Having created this foundation for the action, the preparation of the case proceeds along strictly professional lines. And it is here that the chief educational value of the work appears. The theory of the prosecution and defense must be worked out, the pleadings must be drawn, the evidence must be arranged in proper form for orderly and logical presentation in court, the rules respecting proof must be carefully gone over to insure against exclusion at the trial, the probabilities of objections being raised at the trial must be estimated and contingencies prepared for, instructions properly covering the law of the case must be drawn, the feasibility of employing special interrogatories must be determined, the qualifications of the jurors must be investigated and grounds for challenge fixed upon. In doing all these things the student is really employing the principles of procedure. $\mathrm{He}$ is given a case at large. The entire responsibility for it rests upon him. He must work it out from beginning to end, and his work is essentially a lawyer's work. It calls in question all the knowledge of the principles of procedure which he has obtained in the course of his previous study. He draws his pleadings with a view to his evidence; he prepares his evidence in the light of his pleadings.

His case is no moot question of abstract right, but a living issue to be tried and tested in the delicate balances of the court room. Before him stretches the long road which leads to the jury's verdict, with its dangers and pitfalls, its sharp declivities, its sudden turns. To travel it successfully calls for all his knowledge and skill, all his foresight, alertness, and sound judgment. $\mathrm{He}$ must weigh the possibilities involved in this choice or that, the advantages of success, the consequences of failure. And in every problem which throws its shadow across his path is involved a coordination of the rules of law and the rules of procedure-of the substance and method. Such a discipline is typical of the lawyer's tasks. To meet it success- 
fully is the test of professional preparation.

This preparation may be easily supervised and criticized. A trial brief may be required, which shall contain the results of all the work done preliminary to the trial. Such a brief should contain a clear statement of the theory of the cause of action or defense relied upon, fortified by ample authorities, together with a close analysis of the pleadings filed, to demonstrate both the formal and substantial sufficiency of the pleadings under the theory adopted. It should contain a statement of the possible positions open to the other side, and an analysis of the adversary's pleadings to show their sufficiency or insufficiency, and a specification of the available methods for raising any objections which this analysis may disclose. It should contain a full outline of the evidence available in support of all the issues made in the pleadings, and the witnesses should be listed, each name to be followed with a schedule of the facts to be proved by him. There should be specific references to all doubtful points connected with the admissibility of evidence, and methods of proof, with authorities in support of the positions taken by counsel. There should be a full set of instructions to the jury, each followed by authorities and reasons in support of its form and substance.

Such a trial brief is just what every lawyer should have before him in every case which he tries. To prepare it requires a close and intelligent study of every phase of the case, and represents legal effort highly beneficial to the student and strictly professional in its scope. No student will ordinarily fail to understand his case in all its phases after working out a satisfactory trial brief along these lines.

The trial itself, when it finally takes place, is merely the realization and execution of the plans prepared and exhibited in the trial brief. A jury of students can easily be had who will themselves derive a large benefit from their critical observation of the performances of their classmates. The case will proceed before the jury like an ordinary law case.

But the trial itself should not be looked upon as a mere imitation of an actual lawsuit. As an imitation it amounts to nothing. What the students need is an opportunity to put their knowledge of law and procedure to actual use, and to avail themselves beneficially of those principles about which they obtained a theoretical understanding in their classroom courses. To that end the instructor who presides in the court should not forget that he is instructing students, not impersonating a judge. He should keep the case moving along proper lines. $\mathrm{He}$ should criticize and correct freely. If mistakes occur and are not noticed by the men trying the case, they should be promptly suggested by the judge, and the point involved may be thus brought home very forcibly to the student, with all the flavor of a concrete setting. Frequent questions on the part of the judge as to principles involved in the various steps taken during the course of the trial will emphasize and direct sharp attention to the logical groundwork of the procedural development exemplified in the case. A general criticism of salient features of the trial may well follow the rendition of the verdict.

A practice court conducted along these lines is not an appeal to the spectacular, but a serious educational institution. It is pedagogically sound. It is entirely practicable under the conditions prevalent in modern law schools. It stirs the students to their best efforts, and gives them correct ideas about procedure. It 


\section{Annual Address-Section on Legal Education}

is the only method so far devised for teaching the technique of the profession in a concrete way. It is to the law school what the clinic is to the medical school or the shop to the school of engineering. In short, it presents a synthetic grouping of legal ideas about the trial as the logical center of legal activity.

The law schools have been too unsystematic with their whole procedural program. They have considered procedure courses as an unscholarly necessity-a form of surrender to popular demands. In common-law pleading, which is everywhere taught, the emphasis has been too much laid on the forms of action and the historical aspects of the subject, thus making it a sort of dumping ground for the history of the common law, instead of viewing it as a highly articulated and logical process for developing a foundation for the trial of issues. A broad curriculum would include pleading, both civil and criminal, evidence, trial practice, and appellate procedure, followed by practice court work as a summation or integration of the other branches. Careful instruction along these lines ought to accomplish substantial results in preparing students to do the thing for which the bar primarily exists, namely to practice law. The law schools have an opportunity to do a great work in raising. the standards of practice which all admit are so low in the United States, and in doing something to compensate the American bar for the want of that procedural specializing which makes English legal administration the envy of the world. 